\title{
ECODESENVOLVIMENTO E POLÍTICAS \\ PÚBLICAS REDISTRIBUTIVAS: PERSPECTIVAS DE IMPLEMENTAÇÃO DO ICMS-E EM SANTA
}

CATARINA

Andreza da Cruz

Miguelangelo Gianezini

Kelly Gianezini

\section{INTRODUÇÃO}

SUMÁRIO

A preocupação com a qualidade ambiental do planeta, bem como a evolução da sociedade e a maneira como está se utiliza dos recursos naturais, é motivo de discussão e estudo em diversos níveis educacionais, organizacionais e governamentais. Assim, os propalados impactos das mudanças climáticas têm demandado de governos, universidades, empresas e Organizações não Governamentais, propostas de soluções para os atuais problemas ambientais (GIANEZINI et al., 2012). Tais questões ganharam, nos últimos anos, maior abrangência tanto nos países desenvolvidos, como nos em desenvolvimento (incluindo-se o Brasil), onde os problemas ambientais têm reflexos na população, com destaque para os grupos em maior vulnerabilidade socioeconômica.

No cenário brasileiro, observando a cronologia da legislação ambiental, em 1965, foi aprovada pelo Senado Federal a Emenda Constitucional n. 18 que, por conseguinte, foi incorporada à Constituição Federal de 1967. Com eficácia de lei complementar, tal dispositivo tratava da Reforma do Sistema Tributário, que seria então a gênese do Código Tributário Nacional (CTN). Foi na referida emenda constitucional que nasceu o Imposto sobre Circulação de Mercadorias (ICM) e em 1988, com a atual Constituição Federal, foram incorporadas novas bases de incidências, passando chamar Imposto sobre Circulação de Mercadorias e sobre Prestações de Serviços de Transporte Interestadual e Intermunicipal e de Comunicação (ICMS). 
O ICMS é, portanto, um imposto de competência dos estados e do Distrito Federal, regulamentado pelo artigo 155 da Constituição Federal. O artigo 158 da Carta Magna trata sobre a repartição das receitas tributárias advindas desse imposto, sendo que $25 \%$ do montante arrecadado devem ser distribuídos aos seus municípios, conforme critérios constitucionais. Desse montante, $25 \%$ dividem-se em duas parcelas: $75 \%$ do valor adicionado fiscal ${ }^{1}$ (VAF) nas operações que incidem ICMS em seus territórios e restante (25\%) conforme dispuser a Lei estadual (BRASIL, 1988). Em Santa Catarina, com a Lei n. 8.203, de 26 de dezembro de 1990 , estabeleceu-se que $85 \%$ do ICMS que pertence aos municípios deve ser divididos conforme o VAF e 15\% em partes iguais a cada um dos municípios (SANTA CATARINA, 1990).

Percebe-se que a repartição estipulada pela legislação privilegia os municípios com maior desenvolvimento econômico, os mais industrializados que têm maior capacidade de gerar o imposto em análise. Porém, é na autonomia do estado em utilizar parte do recurso conforme Ihe convier, que aparece o Imposto sobre Circulação de Mercadorias e sobre Prestações de Serviços de Transporte Interestadual e Intermunicipal e de Comunicação Ecológico (ICMS-E). ${ }^{2}$ Trata-se de uma política pública tributário-ambiental, que estimula a preservação e conservação do meio ambiente, buscando a construção de um novo modelo de desenvolvimento sustentável para os municípios, que garantam melhor distribuição dos recursos e justiça social.

\section{BREVE PROBLEMATIZAÇÃO E REFERENCIAL}

Foi no século $X X$ que iniciaram diversos movimentos na busca de conscientização ambiental por parte da sociedade e dos governos, por exemplo, em nível mundial, em 1949, a Conferência Científica da Organização das Nações Unidas (ONU) sobre a Conservação e Utilização

\footnotetext{
${ }^{1} \mathrm{O}$ cálculo do valor adicionado fiscal que corresponde aos Municípios encontra-se expresso na Lei Complementar n. 63/1990, no artigo 3으, parágrafo 1으, inciso I. "[...] ao valor das mercadorias de saída, acrescido do valor das prestações de serviços, no seu território, deduzido o valor das mercadorias entradas, em cada ano civil." (BRASIL, 1990).

${ }^{2}$ Durante a pesquisa bibliográfica e documental, deparou-se com a sigla grafada de duas formas: "ICMS-E" e "ICMS-e". Neste estudo, optou-se pelo uso da caixa alta.
} 
de Recursos e, em 1968, a Conferência sobre Biosfera, realizada em Paris. A publicação do Relatório Limites do Crescimento, elaborado pelo Clube de Roma ${ }^{3}$ e a Conferência de Estocolmo em 1972 buscaram conscientizar os países sobre a necessidade de exploração sustentável dos recursos naturais. Em 1987, um relatório foi elaborado pela Comissão Mundial para o Desenvolvimento e Meio Ambiente (CMDM), o Relatório Brundtlandt ou Our common future (Nosso futuro comum), no qual foi apresentada a definição de Desenvolvimento Sustentável, ${ }^{4}$ colocando a temática na agenda política internacional (BARBIERI, 2011).

Em 1992, foi realizada, no Rio de Janeiro, a II Conferência das Nações Unidas para o Meio Ambiente e Desenvolvimento (Rio 92), essa conferência foi o marco para as discussões sobre gestão ambiental em nível global. A Rio 92 seria a reafirmação da Declaração da Conferência de Estocolmo e a partir dela o conceito de desenvolvimento sustentável foi disseminado pelo mundo. No final daquela década, em 1997, outro evento importante que ocorreu foi o Protocolo de Quioto, ${ }^{5}$ que tinha por objetivo diminuir de 2008 a 2012 em média 5\% as emissões de gases que provocam efeito estufa na atmosfera em relação aos níveis de 1990 (BRASIL, 1997).

Essas demandas guiaram muitas ações em diversos países, que estabeleceram políticas e programas voltados a essa questão. Contudo, o desafio maior reside nos países em desenvolvimento com diversidades regionais, como é o caso do Brasil, onde a inter-relação entre as esferas de organização administrativa federal, estadual e municipal ocorre por

\footnotetext{
${ }^{3}$ O Clube de Roma foi fundado em 1966 pelo industrial italiano Aurélio Peccei e pelo cientista escocês Alexander King. O Roma reunia um grupo de pessoas para debater assuntos relacionados à política, economia internacional, dando ênfase ao meio ambiente e o desenvolvimento sustentável (ALVES; ALBUQUERQUE, 2016).

${ }^{4}$ Conforme o Relatório, a humanidade tem a capacidade e habilidade de promover o desenvolvimento de forma sustentável, assegurando o atendimento das necessidades presentes sem comprometer a capacidade das futuras gerações de suprir as suas. Do original em inglês: "Humanity has the ability to make development sustainable to ensure that it meets the needs of the present without compromising the ability of future generations to meet their own needs." (BRUNDTLAND, 1987, p. 24, tradução livre).

${ }^{5} \mathrm{O}$ Protocolo de Quioto constitui um tratado complementar à Convenção-Quadro das Nações Unidas sobre mudança do clima, definindo metas de redução de emissões para os países desenvolvidos e os que, à época, apresentavam economia em transição para o capitalismo, considerados os responsáveis históricos pela mudança atual do clima (BRASIL, 1997).
} 
meio do cumprimento de direitos e deveres constantes na legislação e nas políticas públicas e sociais.

Ademais, ressalta-se que o Brasil possui 26 estados e um Distrito Federal, sendo que desses, há dezesseis estados que já implementaram o ICMS-E. Todavia, a lei que disciplina o ICMS em cada estado é autônoma, conforme competência outorgada pela Constituição Federal (art. 155, inciso II), assim possibilita os entes a criarem critérios conforme suas necessidades. Em 2003, no estado de Santa Catarina foi proposto o Projeto de Lei Complementar n. 010 que tratava dos critérios de distribuição da parcela de receita do ICMS pertencente aos municípios, porém esse projeto não está mais em andamento (ICMS ECOLÓGICO, 2017). ${ }^{6}$

Com base em dados do Conselho Nacional de Política Fazendária, em dezembro de 2017, o total geral da receita tributária do Estado foi de $\mathrm{R} \$ 1$ 1.907.055.487,00, e desse montante $\mathrm{R} \$ 1$ 1.766.484.217,00 foram o total de arrecadação do ICMS, o que perfaz um percentual de $92,63 \%$, confirmando ser o tributo de maior importância (CONFAZ, 2018). Esses dados e informações contribuem para compreensão de que os recursos não devem ter, apenas, o caráter arrecadatório, reforçando o entendimento de sua utilização na geração de benefícios socioambientais. E, esse novo olhar traduz a necessidade de outra postura da sociedade em relação ao meio ambiente, harmonizando o binômio desenvolvimento e sustentabilidade.

Em alguns municípios, existe limitação quanto ao uso de seu território por haver locais que são protegidos ambientalmente, tornando esses municípios pouco produtivos e com isso sua participação na redistribuição do imposto será menor do que os municípios com menor área de conservação e maior atividade industrial, carecendo assim de políticas - como a que foi o objeto deste estudo - para modificar essa realidade. Neste ponto, por entender que a legislação é meio e não fim, observa-se uma lacuna a qual este trabalho pretendeu preencher, qual

\footnotetext{
${ }^{6}$ Aqui, cabe esclarecer que houve outro Projeto de Lei Complementar (n. 375/2011) idealizado na mesma perspectiva do ICMS-E. No entanto, tal projeto não foi discutido na Assembleia Legislativa de Santa Catarina, pois sequer chegou ser aprovado na Comissão de Constituição e Justiça (CCJ). Desse modo, ao proposta consta em trechos deste texto (uma vez que foi mencionado por alguns dos entrevistados), contudo não foi objeto deste estudo.
} 
seja, a de estudos empíricos acerca das políticas públicas tributárioambientais cujas propostas estejam alinhadas ou não com os princípios do ecodesenvolvimentismo e da justiça social.

Observando a condição catarinense nesse contexto, o estudo propôs alguns questionamentos, a saber: quais as principais ações e agentes envolvidos na proposta de implantação do ICMS-E em Santa Catarina? Por que o mesmo ainda não foi implementado? E, considerando a sua não obrigatoriedade, quais as perspectivas positivas (avanços) e negativas (retrocessos e limitações) desse processo?

Para responder a estas questões foram estabelecidos objetivos voltados à compreensão da proposta de implantação do ICMS-E no estado de Santa Catarina (SC) e avaliação das perspectivas para a sua implementação, incluindo-se aqui: promover um levantamento das características dos modelos de estados que já implementaram o ICMS-E; compilar os requisitos e as informações relacionadas às ações de implantação do ICMS-E em SC junto aos órgãos competentes e associações; averiguar os avanços e retrocessos no processo de implantação dessa política governamental; e analisar os argumentos para implementação ou não do ICMS-E em SC.

Diante desse contexto, foi proposto este estudo acerca da implantação do ICMS-E em SC evidenciando, em perspectiva, as contribuições do ecodesenvolvimentismo em Sachs (1993; 1994; 1995; 2009b; 2012) e das possibilidades das políticas públicas, adaptadas a partir de um rol de autores como Lasswell (1936), Lowi (1972), Sabatier e Jenkins-Smith (1993), Ferreira (1998), Frey (2000), Souza (2006), Saraiva (2006), Schmidt (2008), Lukic (2012), Raeder (2014), Secchi (2015) e Gianezini et al. (2017) - por meio da investigação das discussões e ações em consonância com a legislação do ICMS e quais práticas que estão sendo adotadas em relação ao ICMS-E no referido estado.

\section{PROCEDIMENTOS METODOLÓGICOS}

Para a consecução desta pesquisa pretendeu-se englobar um estudo exante exploratório, aplicado e qualitativo. Há estudiosos que 
propõem as políticas públicas possam ser avaliadas como ex post ou ex ante (FERREIRA, 1998; FREY, 2000; SARAIVA, 2006; SOUZA, 2006; SCHMIDT, 2008; RAEDER, 2014; SECCHI 2015; GIANEZINI et al., 2017). A opção aqui escolhida foi pela avaliação ex ante, com o fito de compreender e avaliar à decisão de implementar ou não o ICMS-E em SC. Destaca-se, nesse tipo de avaliação, o diagnóstico (ou estudo da situação), quando se mapeiam as necessidades e são realizados estudos de factibilidade que orientarão a formulação de uma política ou programa.

Em complemento, Khandker, Koolwal e Samad (2010) explicam que se podem realizar estudos prospectivos (ex ante), com intuito de dimensionar os possíveis benefícios ou obstáculos de uma intervenção, simulando-se situações futuras (com e sem a implementação da política), e de se utilizar o modelo de análise estrutural que identifica os principais agentes envolvidos (indivíduos, comunidades, governos, dentre outros), suas interações e os diferentes contextos que influenciam os resultados do programa. Para os autores, tais procedimentos colaboram com "[...] o refinamento das ações antes mesmo da sua implementação, ao prever seus efeitos potenciais em diferentes ambientes." (KHANDKER; KOOLWAL; SAMAD, 2010, p. 3). Além das políticas públicas, a avaliação ex ante também é recorrente em uma de suas variantes, que são os projetos sociais (GIANEZINI et al., 2017), sendo realizada antes da execução do programa/projeto. ${ }^{7}$

Em relação aos objetivos, a pesquisa foi predominantemente exploratória, haja vista que até o presente momento não se constatou publicação de estudo específico sobre a política pública selecionada para a pesquisa em SC. Além disso, pode-se dizer que esse tipo de pesquisa busca proporcionar maior familiaridade com o problema, tornando-o mais explícito e (re)conhecido no meio acadêmico-científico como objeto de estudo e pesquisa (SELLTIZ et al. 1967).

\footnotetext{
${ }^{7}$ Nestes casos, segundo Cohen e Franco (2007, p. 18), sua finalidade é “[...] proporcionar critérios racionais para uma decisão qualitativa crucial: se o projeto deve ou não ser implementado. Também permite ordenar os projetos segundo sua eficiência para alcançar os objetivos perseguidos". Podem-se mencionar outras variantes e terminologias como a avaliação "marco zero" também encontradas na literatura, uma vez que "[...] ocorrem antes da instalação de um determinado programa e servem para orientar a equipe responsável por ele no planejamento das ações, garantindo o máximo de proximidade às reais necessidades e expectativas dos futuros usuários." (CHIANCA; MARINO; SCHIESARI, 2001, p. 18).
} 
Por conseguinte, a pesquisa realizada teve abordagem qualitativa, apontada por Creswell (2010, p. 26) como "[...] meio para explorar e para entender o significado que os indivíduos e grupos atribuem a um problema". Além disso, a abordagem qualitativa permitiu analisar os dados indutivamente em "[...] análise construída a partir de particularidades para temas gerais e interpretações feitas pelo pesquisador acerca do significado dos dados." (CRESWELL, 2010, p. 26). Tal abordagem foi fundamental para o delineamento do lócus de estudo, qual seja o estado de Santa Catarina, localizado no Sul do Brasil, com um território de 95.737,895 km² (IBGE, 2017) e 295 municípios, população estimada de 6.910 .553 e densidade demográfica de 65,29 hab./ $\mathrm{Km}^{2}$ (IBGE, 2017). Diante desses dados, foram coletados documentos e informações que auxiliaram a compor o referencial e parte dos resultados, incluindo a apresentação do ICMS-E, bem como, um framework ilustrativo, para melhor representação dos elementos do estudo, contribuindo para a delimitação da coleta e análise dos dados.

Figura 1 - Framework representativo do estudo

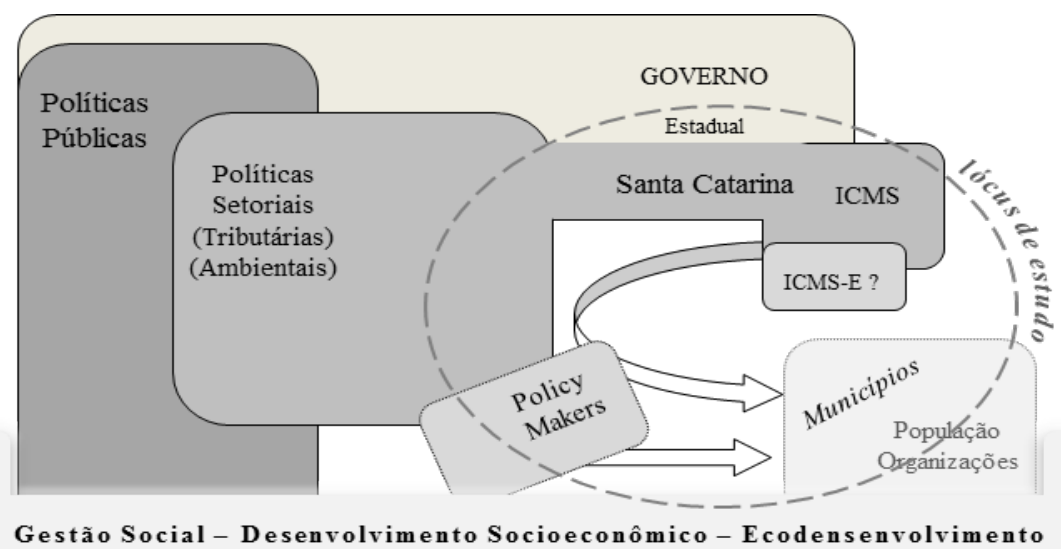

Fonte: Adaptado de Gonçalves, Gianezini e Estevam (2018)

No framework, observam-se as esferas governamentais, as políticas tributárias e ambientais como setoriais dentro do campo das políticas públicas, os atores, o recorte, objeto de estudo (ICMS-E) e o lócus catarinense, sendo todos esses elementos enquadrados na moldura 
do Desenvolvimento Socioeconômico e Gestão social, em diálogo com o Ecodesenvolvimento.

\section{PROCEDIMENTOS DE COLETA E ANÁLISE DE DADOS}

Preliminarmente, buscaram-se subsídios para a compreensão da temática e referencial, a partir de estudo bibliográfico (que em parte já está publicado), pois se baseia em livros, periódicos científicos e websites que se entende terem sido relevantes ao trabalho. Nesse contexto, a pesquisa bibliográfica sistemática ocorreu em livros e artigos científicos disponíveis nas bases de dados Scientific Electronic Library Online (SciELO) e Google Scholar ${ }^{\circledast}$, realizada no primeiro semestre de 2017, utilizando-se especialmente as seguintes palavras-chave em português: ecodesenvolvimento e ICMS-ecológico. A posteriori, de agosto de 2017 a janeiro de 2018, houve uma segunda parte que abrangeu o estudo junto aos órgãos e agentes, valendo-se da técnica de levantamento e pesquisa documental (de gabinete e a campo), além, de entrevistas semiestruturadas com agentes envolvidos no processo de implantação da política (ICMS-E).

O contato, a coleta de informações e as entrevistas com os agentes envolvidos nas iniciativas em prol da implantação e implementação do ICMS-E em SC foram essenciais para alcançar os objetivos propostos. Inicialmente, o contato se deu com funcionários da Assembleia Legislativa de SC na busca por legislação e informações sobre o trâmite de votação do projeto, como forma de compreender as variadas etapas até o seu arquivamento. Em um primeiro momento, houve a abordagem telefônica com um funcionário que disponibilizou via e-mail os arquivos relacionados aos projetos sobre o ICMS-E que por lá tramitaram, iniciando assim a pesquisa documental. Paralelamente, a pesquisa bibliográfica estava em fase de conclusão.

Colhidas tais informações, o passo seguinte foi o de identificação das pessoas para as entrevistas. A amostra caracterizou-se como autogerada tendo sido escolhidas aquelas que participaram ativamente na fase de elaboração e trâmite do Projeto de Lei Complementar n. 010/2003. Cabe ressaltar que, nessa seleção, foi detectado outro projeto 
sobre a mesma temática - Projeto de Lei Complementar n. 035.7/2011 que nem mesmo chegou a ser discutido por apresentar "vício de origem" 8 e consequentemente reprovado pela Comissão de Constituição e Justiça (CCJ). Entretanto, por opção desta pesquisa o deputado responsável pela propositura foi entrevistado, afinal, o objetivo de tal projeto era distinto do projeto inicial.

Por conseguinte, foram realizadas as demais entrevistas. Inicialmente com o deputado responsável pela elaboração do primeiro projeto, em 2003, bem como seu assessor, que por deter maior conhecimento na área ambiental, foi quem coordenou todas as etapas. Foi entrevistada também, a funcionária da Fundação de Amparo à Tecnologia e Meio Ambiente (FATMA), que à época da implantação desenvolvia tese de doutorado sobre ICMS-E. E por fim, a entrevista com o presidente da Federação Catarinense de Municípios (FECAM), no intuito de compreender a diversidade de percepções dos policymakers envolvidos na implementação. Cabe salientar que cada entrevista foi precedida de apresentação do Termo de Consentimento Livre e Esclarecido. Assim, todas as informações prestadas pelos entrevistados foram utilizadas unicamente para a compreensão acerca do objeto de estudo, seguindo os questionamentos semiestruturados.

Eis os perfis dos entrevistados, com seus respectivos cargos atuais e os cargos que ocupavam no período da implantação e tentativas de implementação da política estudada: E1 - Prefeito; 47 anos; mestre em Geografia; na época assessor do deputado responsável pela propositura do Projeto de Lei Complementar n. 010/2003; E2 - Empresário; 55 anos; graduado em Gestão Pública; na época deputado estadual, autor do Projeto de Projeto de Lei Complementar n. 010/2003; E3 - Aposentada; 58 anos; doutora em Engenharia Florestal; funcionária da FATMA na época em que ocorreu a elaboração do Projeto; E4 - Deputado, 47 anos; graduado em Jornalismo; na época autor do projeto de Projeto de Lei Complementar n. 035.7/2011; e E5 - Funcionário Público; 57 anos; graduado em Ciência da Computação e Administração de Empresas; presidente da FECAM na

\footnotetext{
${ }^{8} \mathrm{O}$ vício de origem apresentado neste projeto foi que a iniciativa deveria partir do Poder Executivo, conforme preceitua a Constituição Estadual de Santa Catarina e neste caso foi proposto pelo Poder Legislativo, sendo assim rejeitado pelo CCJ.
} 
época em que ocorreu a propositura do Projeto de Lei Complementar $\mathrm{n}$. 010/2003.

A coleta a campo contemplou dados primários e secundários. A coleta de dados secundários ocorreu em documentos oficiais e publicações fornecidas pelos agentes (ou solicitadas) nos órgãos/instituições visitadas. E, como já mencionado, os dados primários foram obtidos por meio de entrevistas, realizadas nos locais previamente escolhidos, observando roteiro estabelecido em questionário semiestruturado.

Vale destacar que as entrevistas foram realizadas no segundo semestre de 2017 e início de 2018, nas cidades de Braço do Norte, Florianópolis e Araranguá. Considerando a distância, duas das entrevistas foram realizadas com auxílio do software Microsoft Skype ${ }^{\mathrm{TM}}$. As entrevistas foram gravadas e transcritas, sendo posteriormente encaminhado para o e-mail de cada entrevistado para a aprovação do conteúdo, retornando o texto devidamente revisado e autorizado a sua publicação.

As entrevistas e documentos foram analisados, sendo então conduzida a extração de excertos que corroboraram na resposta ao problema e consecução dos objetivos propostos. Foram transcritos trechos das entrevistas compilados de acordo com categorias e confrontados com o referencial teórico para a discussão. Aqui cabe mencionar o caráter indutivo do estudo e como tal, a partir de seus achados emergiram as categorias de análise ligadas ao referencial.

\section{ESTADOS QUE IMPLEMENTARAM O ICMS-E E A INICIATIVA CATARINENSE}

O primeiro objetivo proposto, foi o de promover um levantamento dos estados que já implementaram o ICMS-E, a fim de compreender quais critérios de distribuição desse imposto foram utilizados por eles (onde e de que forma), quais porcentagens direcionadas a cada critério (quanto), bem como identificar o marco legal (como) e a data de implementação (ano). Os resultados do levantamento estão sintetizados no Quadro 1. 


\section{Quadro 1 - Estados que já implementaram o ICMS Ecológico no Brasil}

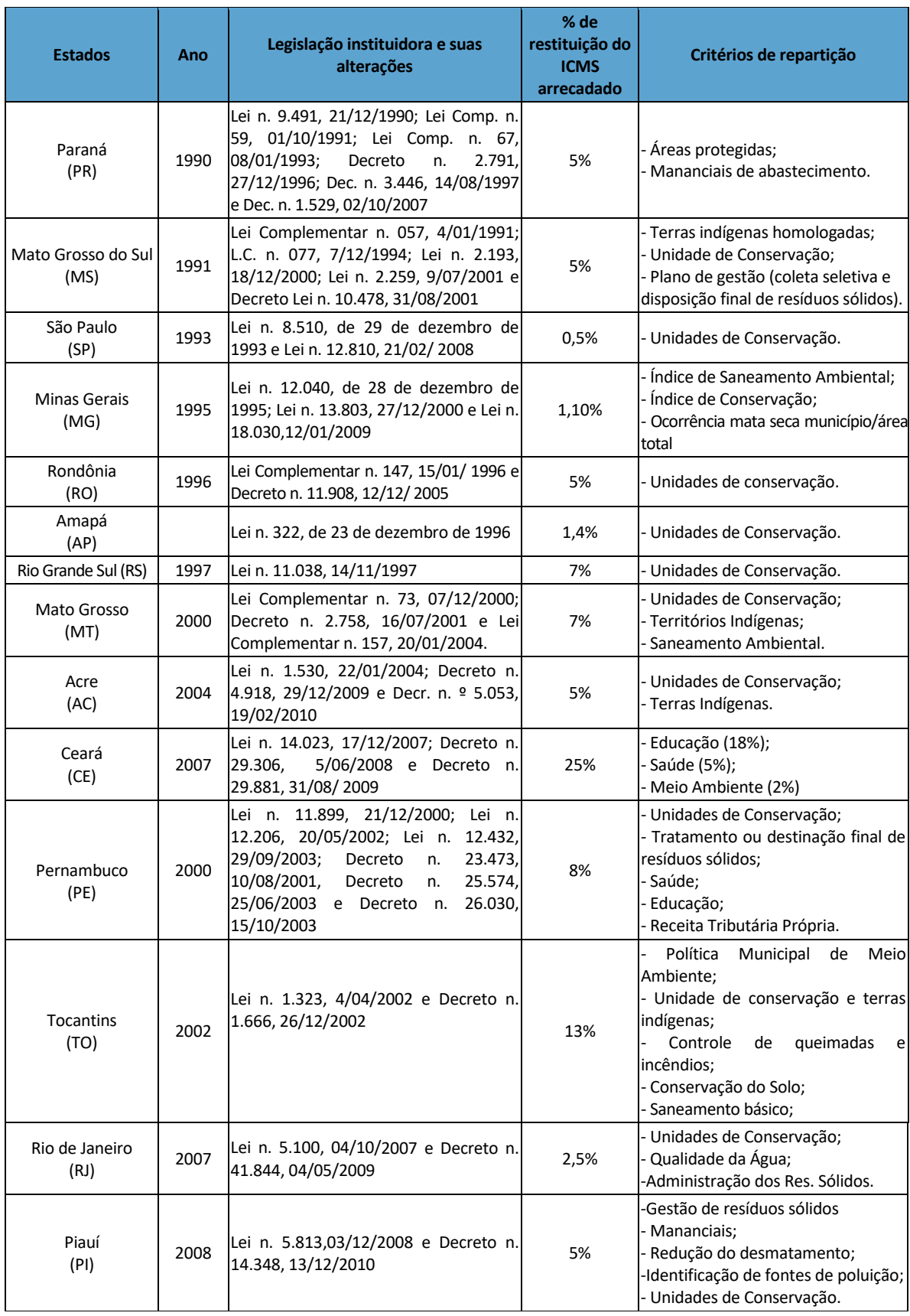


no Sécullo

\begin{tabular}{|c|c|c|c|l|}
\hline Estados & Ano & $\begin{array}{c}\text { Legislação instituidora e suas } \\
\text { alterações }\end{array}$ & $\begin{array}{c}\text { \% de } \\
\text { restituição do } \\
\text { ICMS } \\
\text { arrecadado }\end{array}$ & \multicolumn{1}{c|}{ Critérios de repartição } \\
\hline $\begin{array}{c}\text { Paraíba } \\
\text { (PB) }\end{array}$ & 2011 & Lei n. 9.600, 21/12/2011 & $10 \%$ & $\begin{array}{l}\text { Unidade de Conservação } \\
\text { Públicas/Privadas (5\%); } \\
\text { Tratamento do Lixo Domiciliar } \\
\text { (5\%). }\end{array}$ \\
\hline $\begin{array}{c}\text { Goiás } \\
\text { (GO) }\end{array}$ & 2011 & Lei Complementar n. 90, 22/12/2011 & $5 \%$ & $\begin{array}{l}\text { - Unidades de Conservação; } \\
\text { - Mananciais Públicos. }\end{array}$ \\
\hline
\end{tabular}

Fonte: Elaborado pelos autores deste capítulo

Por meio da pesquisa documental foi possível identificar que dos 26 estados brasileiros (e o Distrito Federal), 16 já implementaram o ICMS-E depois de 1991 (ICMS ECOLÓGICO, 2018) e são utilizados diversos critérios de distribuição, levando em conta a realidade de cada um.

Figura 2 - Estados que já implementaram o ICMS-E, 2018 (em verde)

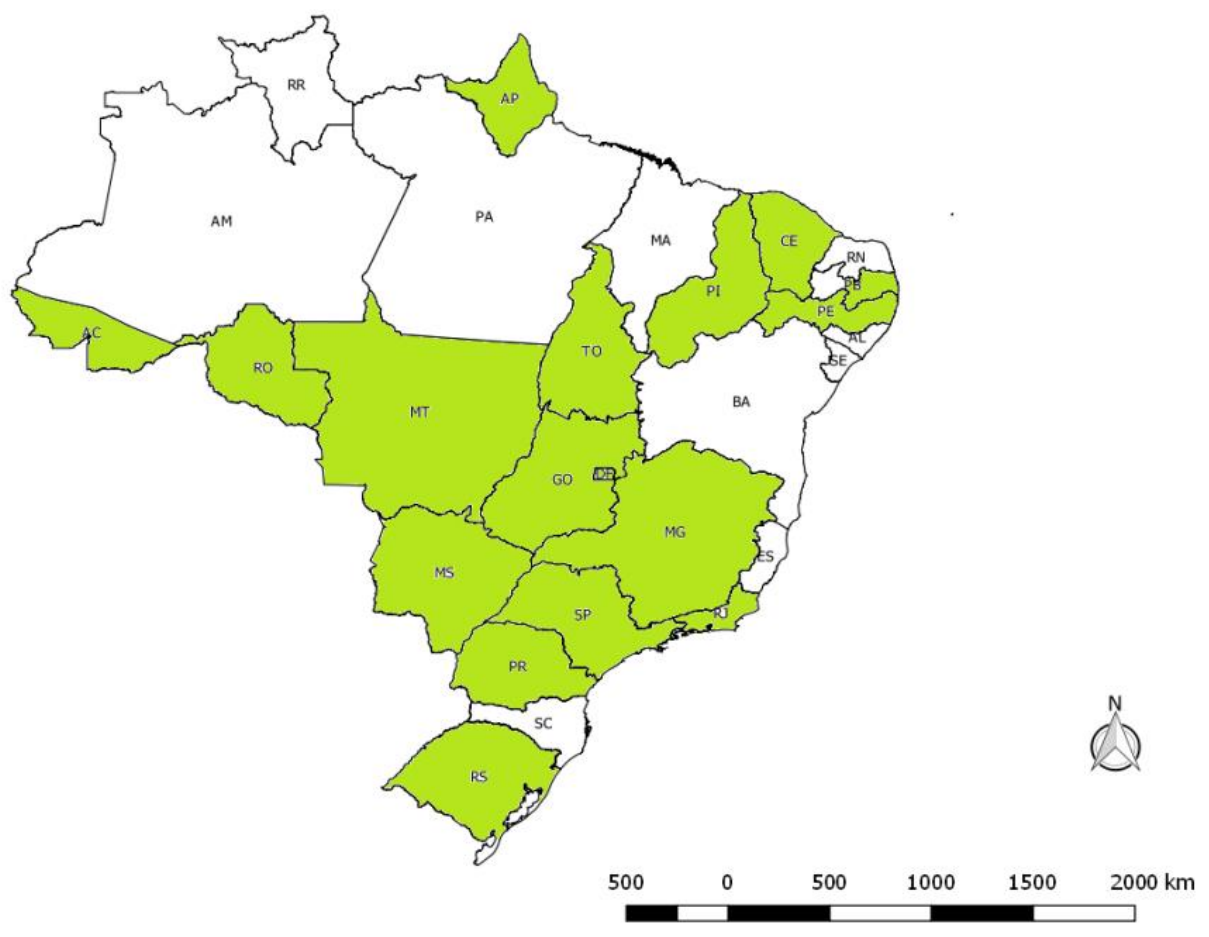

Fonte: Elaborada pelos autores deste capítulo 
Na compilação, pode-se destacar a variação nos percentuais de restituição do ICMS arrecadado. O percentual mais baixo, de 0,5\% está no estado de SP e o mais elevado encontra-se no estado do $\mathrm{CE}$, totalizando $25 \%$. O percentual de $5 \%$ foi o mais comum entre os estados do PR, de MS, de RO, do AC, do PI e de GO. Sobre os critérios de distribuição, embora o estado do CE tenha o maior percentual de restituição do ICMS-E, foi o único estado que não apresentou em seus critérios unidade de conservação, apenas consta como a destinação de $2 \%$ ao meio ambiente de modo geral. Todos os demais apresentam em seus critérios unidade de conservação. Ressalta-se a experiência dos estados de MS, de MT e do $A C$ que em seus critérios apresentam as terras indígenas, bem como o TO que utilizou o controle de queimadas e o PI o critério desmatamento, reforçando assim, a utilização critérios conforme necessidade apresentada em cada território.

Por conseguinte, para complementar os resultados desta seção, também são apresentados trechos das entrevistas, nos quais os agentes entrevistados mencionam as experiências inicialmente consultadas como subsídio ou exemplo para o projeto catarinense. O estado de Santa Catarina buscou no início da discussão, mais precisamente na fase de elaboração do projeto, auxílio com outro estado (Mato Grosso), que já houvera implementado o ICMS-E. Entretanto, conforme informações prestadas por um dos entrevistados (E1), o modelo mato-grossense ia de encontro das necessidades de Santa Catarina.

[...] alguém orientou a gente ir ao Mato Grosso e por incrível que pareça nós fomos no pior modelo, no início, [...] eles tinham já uma lei que estava em prática, só que os critérios de distribuição eram complexos, então tinham vários quesitos de distribuição, tinha: território, unidade conservação, manancial, até estrada [...] Eu não sei se eles continuam com esse mesmo projeto, mas de todos que havia naquela época e havia muitos eu não lembro agora quantos estados já tinham aderido, [...] já tinham essa lei, mas talvez este fosse o pior exemplo, ele era muito complexo, não sei nem se estavam colocando em prática. (E1). 
Posteriormente, por ser um modelo inadequado para as necessidades que se apresentavam na época, a equipe procurou novas experiências em busca de implementar o projeto. Nesse momento descobriu-se o estado pioneiro do ICMS-E no Brasil. Trata-se do estado do Paraná.

[...] depois, quando a gente descobriu o do Paraná, já mudou um pouquinho de foco, se viu que o Paraná era muito mais centrado, era também um projeto mais enxuto e assim, não era tão conflituoso, porque era um projeto que atendia a necessidade dos municípios [...] e que havia sóz dois critérios, que seria unidade conservação e mananciais de abastecimento público, então pra nós, era aquilo que a gente precisava, não precisava tudo aquilo que tinha lá no projeto do Mato Grosso. (E1).

Observando as distintas experiências compiladas no quadro síntese, aliadas às declarações mencionadas é possível compreender que a criação de um projeto de lei, para implementar o ICMS-E nos estados, deve levar em consideração sua realidade e necessidade, seja ela social, econômica ou ambiental, não se valendo de modelos prontos aplicados a macro realidades distintas. Essa constatação, ainda que guarde obviedade, vai ao encontro do que assevera a proposta ecodesenvolvimentista de Sachs (2009b), em especial no que tange à necessidade de planejamento no nível micro. Ou seja, um planejamento local e preferencialmente participativo, envolvendo não apenas as autoridades locais, mas também comunidades e associações de cidadãos envolvidos na proteção das áreas.

Assim, tendo em conta a realidade de cada estado, cabe relembrar Souza (2006), para quem a formulação de políticas públicas requer envolvimento multidisciplinar, pois que seus resultados repercutirão em diversas áreas como economia, ciência política, gestão, antropologia, geografia, planejamento, sociologia, entre outras. 


\section{MOTIVAÇÕES, REQUISITOS E INFORMAÇÕES ACERCA DAS AÇÕES DE IMPLANTAÇÃO DO ICMS-E EM SANTA CATARINA}

Nesta seção, apresentam-se as motivações que levaram a propositura do projeto em análise. Cada entrevistado abordou de maneira distinta suas intenções. O idealizador do projeto original, aqui identificado como E2 (à época era deputado estadual, autor do Projeto de Lei Complementar n. 010/2003), explica suas motivações:

Quando nós definimos um planejamento para o mandato, [...] nós iriamos focar o meio ambiente, começamos a estudar, pesquisar tudo que eram alternativas no Brasil e apresentar para Santa Catarina. E, o que me levou a apresentar esta ideia especificadamente, foi justamente ter nascido em um município como Imaruí, uma cidade muito pobre, que tem uma dificuldade muito grande [...] ajudar esses pequenos municípios a desenvolverem $e$ saber que esse desenvolvimento ia atingir diretamente o cidadão que mora ali, porque esse cidadão teria uma qualidade de vida melhor. Então era isso que nos motivou a ajudar quem mais precisava. (E2).

Para tanto, alcançar sucesso foi definida como "bandeira de luta o meio ambiente" (E2), expõe o entrevistado a necessidade de colaboração de outros agentes, que nesse caso em especial, foi a participação de seu assessor, hora representado como E1:

Levei para trabalhar na minha assessoria [...], que é um amigo pessoal que eu tenho, é até hoje um grande amigo, vice-prefeito de Imaruí, formado nesta área, enfim, um especialista. Esse cara me ajudou muito e nós fomos atrás de ideias boas para Santa Catarina, e uma delas e a que melhor veio ao encontro daquilo que a gente queria, que se propunha na época, é [...], que era a participação popular para a questão ambiental, foi a ideia para o ICMS Ecológico. (E2).

Ao questionar E1 (à época assessor do deputado responsável pela propositura do Projeto de Lei Complementar n. 010/2003) sobre suas 
motivações em coordenar tal Projeto com tanto afinco (conforme relatou E2 em suas declarações) observa-se que se trata de uma motivação muito influenciada por suas convicções pessoais, originadas ainda na infância.

Primeiro porque eu já tinha uma certa tendência assim na questão ambiental, [...], uma outra coisa, porque eu nasci em Imaruí, e lá tinha o parque. Este parque cobre 75\% do território, a ideia da preservação dos mananciais era super importante para nós, porque nós tinha dentro do parque vários mananciais que abasteciam Imaruí, que abastece Imaruí, várias comunidades abastece Imbituba [...] ai em 2003, no auge deste projeto teve uma estiagem, quase todos os mananciais que estavam fora do parque secaram e os do parque continuaram, então aquilo ajudou bastante a gente [...] a gente ficou bastante sensibilizado com aquilo, olha só, se a gente não tivesse o parque, eu sou defensor do parque [...] até hoje defendo o parque, se não tivesse o parque hoje aqui nós teríamos perdido bastante vegetação e teria perdido os mananciais do parque. (E1).

Com a mesma tendência voltada às questões ambientais, a entrevistada E3 (à época funcionária da FATMA), relatou que fazia um trabalho em comunidades de SC sobre a necessidade de preservação e conservação ambiental, na qual aquelas regiões que conservavam e protegiam acabavam por ficar sem os recursos que consequentemente $o$ meio ambiente proporcionava a elas.

Tinham umas 40 familias e nós fomos entrevistar as famílias, eu comecei a notar [...] o que eles não têm, que eles não têm escola, que eles não têm dentista, que eles têm que sair da cidade deles, da localidade, para ser muitas vezes favelados, não só em Santo Amaro como na região de Florianópolis, eu comecei a me dar conta daquilo que eu te falei, que eles estão pagando pelo nosso bem-estar e que seria justo uma parte desse recurso voltar pra eles. Foi essa minha motivação principal nasceu na Vargem do Braço. Fiz na Vargem do Braço um projeto de microbacias, foi lá que nasceu, que 
eu comecei a ver se eu estou gerando bem-estar para alguém continuadamente, alguém tem que me pagar por isso, porque eu não posso viver pobre [...] enquanto eu estou gerando água para outras pessoas, que eu estou gerando manutenção hídrica, regulação de chuva, todos os benefícios da preservação. (E3).

E, com relação à motivação do responsável pelo segundo projeto de lei apresentado na Assembleia Legislativa em 2011 (PL 35.7/2011), o entrevistado E4 (à época deputado estadual, autor do projeto de projeto de lei citado) declarou que buscou atender ao pedido de parte da população, que se preocupa com a questão ambiental.

Eu sempre fui aquele canal de ouço aqui e levo aqui. Eu trouxe isso pro meu mandato. Esse projeto do ICMS ecológico, ele é um dos resultados de um trabalho que fiz sobre o gerenciamento dos resíduos sólidos. [...] em 2010 eu fiz uma série de viagens, porque nós tínhamos prazos para apresentar nosso plano estadual, os municípios tinham os prazos deles, o estado tinha e eu decidi fazer uma contribuição. [...] Neste estudo meu do gerenciamento de resíduos sólidos eu conheci uma engenheira ambiental que me trouxe esse projeto do ICMS ecológico, foi uma bandeira dela também, ela é lá de Joinville, ela criou e eu olhei e achei muito interessante. (E4).

Observadas essas motivações, passa-se a apresentação dos requisitos e as informações relacionadas às ações de implantação do ICMS-E em Santa Catarina junto aos órgãos competentes e associações. Para tal foram entrevistados a funcionária da FATMA e o presidente da FECAM da época, como subsídio para compreender a não implementação desse projeto. Segundo os entrevistados foram efetuados diversos debates para apresentação do projeto e eventuais resultados no caso de sua implementação. Conforme dito pelo entrevistado E5 (à época presidente da FECAM quando se deu a propositura do Projeto de Lei Complementar n. 010/2003): 
A sistemática era a seguinte: eram organizadas pautas no âmbito estadual e no âmbito regional das associações regionais de municípios, tá! E em Santa Catarina isso é bem estruturado, os municípios se organizam no âmbito de associações regionais e ali discutem os interesses com a União. E no âmbito estadual, essas associações, então, se juntam associação de município, para discutir no contexto da FECAM, da Federação Catarinense de Municípios. Então eram feitas pautas regionais e de interesse regional e de interesse estadual. $O$ órgão estadual que liderava isso era a FATMA, fundação de apoio de tecnologia e meio ambiente. E a FATMA dava o suporte no sentido de bem orientar, né! Porque eles são os especialistas, na verdade. É a parte técnica. Como o município participava com a sua área ambiental, diretoria, sua secretaria, dependendo do porte do município, a sua fundação de meio ambiente, muitos municípios tinham isso estruturado, então, se juntavam regionalmente. E no âmbito estadual também. E estava bem avançado essa matéria, até não sei por que que não aprovaram isso, né! (E5).

Essas pautas descritas pelo entrevistado E5, representam a segunda fase do ciclo das políticas públicas, a agenda-setting ou a inserção na agenda. Conforme assevera Schmidt (2008, p. 2.316), esta fase ocorre quando "[...] problemas e assuntos que chamam a atenção do governo e dos cidadãos. [...] não se trata de documento escrito ou formal, e sim do rol das questões debatidas pelos agentes públicos e sociais com forte repercussão na opinião pública". Por fim, nessas discussões que ocorriam das mais variadas formas, eram apresentadas simulações efetuadas pela Fazenda Estadual, para que os prefeitos, muitas vezes representados pelas Associações de Municípios com o acompanhamento da FECAM, pudessem visualizar quais seriam suas perdas ou ganhos. Esse momento foi essencial para compreender o terceiro e quarto objetivos específicos apresentados. 


\section{PERCEPÇÕES E ARGUMENTAÇÕES À IMPLEMENTAÇÃO DO ICMS-E}

Alguns entrevistados (E1 e E3) entenderam que a apresentação dos valores (simulação de demonstrativos de resultado) representou um retrocesso, embora na própria representação restava evidente se tratar de um valor considerado insignificante para um município de grande porte, sendo isso possível ser detectado na declaração do E1 e E3, respectivamente:

Para os municípios que iam perder a gente não levou. Mas iam perder tão pouco, praticamente insignificante porque nos municípios maiores por exemplo [...] imagina o seguinte, o Municipio de Imaruí recebe $R \$ 3.500 .000,00$ de ICMS por ano, se viesse $R \$ 200,000,00$ a mais já estava muito bom pra nós, só que $R \$ 200.000,00$ no Município de Joinville, que recebe milhões, sei lá cento e pouco, duzentos mil, [...] não é nada, não vai fazer diferença para eles. Do mesmo modo Blumenau, é isso que a gente levava para eles. Tu imaginas o seguinte, $o$ Município de São Martinho, o ICMS deles é menor que o nosso ainda, mas se eles ganhassem $R \$ 500.000,00$ ou $R \$ 300.000,00$ de ICMS para eles era muita coisa. (E1).

Santa Catarina a arrecadação é mais baixa, então em um percentual muito pequeno [...] tem municípios que não fariam diferença nenhuma, mas a questão que a gente usou a simulação para mostrar do que sai de Blumenau, vai para Pomerode, fica na região. Então, continua beneficiando, só que melhor distribuído, mas justamente, menos injustamente. Mas a gente fez várias reuniões em Blumenau, em Joinville, na verdade o que mais impediu o município que se colocou contra mesmo, e que era na época o município do governador, foi Joinville. (E3).

Entretanto, o entrevistado E5, representante da FECAM, manifestou posicionamento contrário com relação aos interesses dos municípios maiores, que concentravam grandes indústrias e 
consequentemente pelo Valor Adicionado (VA) recebiam maior retorno do ICMS.

Eu acho que os municípios maiores, eles também têm interesse na aprovação, só que o que estava, talvez o lobby que viesse a ocorrer em cima dos critérios de distribuição. Os municípios menores têm menos barganha política, né? Mas, digamos assim, o interesse maior, o critério maior de distribuição, focava em áreas de preservação permanente, que em parte, enfim [...], reservas, no âmbito do território do munícipio e os municípios maiores, onde cediam as grandes indústrias, os grandes empreendimentos industriais queriam que também priorizassem esses critérios, que dessa mais prioridade pra esses critérios, digamos assim. Então essa era a discussão política [...] (E5).

Para a entrevistada E3 o retrocesso em relação a não aprovação do Projeto de Lei foi exclusivamente por falta de interesse da FECAM, sendo possível detectar no excerto declarado.

[...] convencer o prefeito, é muito difícil. É mais fácil conversar com a FECAM, porque eles têm mais conhecimento. Mas eles são mais conservadores. E quem manda na FECAM não é governador, não é político, não é prefeito, são eles mesmos. Então, o principal empecilho foi a FECAM. Foi a própria FECAM. (E3).

O critério de distribuição proposto pelo projeto não foi acolhido de maneira positiva pela FECAM, entendendo trazer prejuízos aos municípios que já apresentavam dificuldades financeiras e que tal redistribuição poderia agravar ainda mais a situação. Isso pode ser apreciado nas declarações dos entrevistados E1 e E3, respectivamente.

[...] a FECAM queria que fosse dos $75 \%$, então no final assim, quando fechou o Projeto e a FECAM veio e disse: "não, a gente não aceita que seja dos municípios" [...] a FECAM, Federação dos Municípios, eles tinham 
comprado a briga dos municípios maiores e falou tudo bem, a gente aceita o projeto mais não aceitamos que $o$ projeto que o recurso seja dos $25 \%$, nós queremos que o recurso seja dos 75\%, ou seja, da parte do Estado. (E1).

Talvez tivesse que ser assim, mas mesmo porque mexer nesses 25\% do município [...], o municipio já é pobre de receita, né? Então, compromete e precisa assistir a população com isso, preservar o meio ambiente. Então, tem que ter mais recurso, tem que ter novo recurso, tem que ter nova forma de distribuição, mexer nesse atual não vai surtir efeito, o município vai passar mais dificuldade ainda e aí não vai conseguir preservar o meio ambiente, como gostaria. (E5).

Em tais declarações, ficou demonstrado que a FECAM tinha interesse em aprovar o projeto, desde que não modificasse os percentuais já utilizados como distribuição (VA), mudando assim o percentual arrecadado pelo estado de Santa Catarina. Por um lado, em relação aos retrocessos, foi possível detectar nos trechos apresentados uma tendência para não aprovação do Projeto por parte dos munícipios maiores e da própria FECAM. Já por outro lado, os agentes entrevistados demonstraram percepções similares de modo geral, em relação a não implementação da lei em SC, quais sejam, os municípios maiores não evidenciavam interesse por terem como consequência a diminuição de sua arrecadação. Por fim, outra peculiaridade importante - sinalizado na declaração do entrevistado E2 - foi em relação à falta de apoio encontrado por parte do governo. Isso alcançou o último objetivo específico proposto, no qual buscava analisar os argumentos para implementação ou não do ICMS-E em SC.

[...] o governo não demonstrou facilidades, o governo não disse em nenhum momento que queria aquilo. É claro, se é um governo parceiro e diz [...] "deputado, vá em frente que eu quero esse projeto" [...] se dissesse isso para os prefeitos com certeza teria facilitado e muito, mas não teve essa compreensão de um governo como um todo, nem do secretário de meio ambiente. (E2). 
Muito embora, os agentes envolvidos participaram com motivações diferentes, ao se comentar sobre as expectativas, o resultado era unânime, qual seja, utilizar da política pública tributário-ambiental ICMS-E, para assim cuidar da qualidade do meio ambiente, desenvolver-se sustentavelmente e manter o equilíbrio socioeconômico. Essas motivações distintas dos agentes envolvidos na fase de implantação dessa política pública tributária-ambiental corroboram com a abordagem proposta por Sabatier e Jenkins Smith (1993), chamada coalizão de defesa, na qual uma diversidade de atores compartilham crenças, valores e ideias distintas na busca de um único propósito, nesse caso, o meio ambiente.

Com relação ao Projeto de Lei Complementar n. 035.7/2011, a proposta era completamente distinta, indo ao encontro do que os municípios e a FECAM buscavam. Todos desejavam não modificar a distribuição dos $25 \%$ que era repassado conforme $\mathrm{VA}$, mas sim utilizar-se dos $75 \%$ que fica para o estado, ou seja, seria uma nova forma de arrecadação. Ocorre que, nesse caso, por alterar a forma de tributação do estado, foi considerado pela CCJ com vício de origem, sendo rejeitado e por isso encontra-se arquivado.

Com base nas declarações do E4, esse projeto encontra-se "[...] nos bastidores de entidades aptas a propositura do Projeto e fazendo assim o caminho inverso". Segue ainda declarando que "[...] é mais fácil convencer apenas um, o governador, do que convencer 295 prefeitos com prioridades distintas." (E4). Portanto, foi possível perceber que existiam muitos obstáculos nesse caminho, em especial, a força dos municípios maiores e a FECAM em não aprovar pelo motivo já exposto, qual seja, diminuir a sua arrecadação.

\section{PERSPECTIVAS DO ICMS-E COMO POLÍTICA PÚBLICA EM SC}

Como observado nas declarações dos entrevistados, o ICMS-E é uma ferramenta que pode ser revertida em ganhos para os estados que a implementarem em seus territórios. Entretanto, diversos podem ser os obstáculos, como demonstrado na experiência de SC. Ainda assim, mesmo que a preservação e conservação ambiental precisem ser vistas como prioritárias, cabe mencionar que não são as únicas razões motivadoras. Isso porque não se trata de uma questão idílica, havendo outras necessidades como o desenvolvimento e sustentabilidade das localidades, 
por exemplo. A concretização de ideias do ecodesenvolvimento ocorre de várias formas, sendo algumas mais ou menos fiéis aos seus preceitos. Portanto, ainda que parcialmente, a política do ICMS-E vai ao encontro do ecodesenvolvimentismo, no sentido de utilizar-se de um instrumento tributário ambiental para a preservação e/ou conservação do meio ambiente e consequentemente fomentar o desenvolvimento econômico e social das regiões que o implementarem. ${ }^{9}$ Nesse sentido, conforme Sachs (2009a, p. 75), "[...] geralmente, essas negociações são dolorosas devido aos interesses antagônicos [...]", afinal, a proposta do projeto inicial era justamente modificar os critérios de redistribuição do ICMS. Isto faria com que os municípios com maior arrecadação, mais industrializados, suprimissem parte do repasse para compensar os municípios impedidos de produzir por possuírem em seu território áreas que deviam ser protegidas. Logo, os municípios mais industrializados, consequentemente com maior retorno em relação ao VA, não apresentaram interesse em tal instrumento. Nesse sentido, no Quadro 2 a seguir, apresentam-se os 12 municípios selecionados em relação à maior participação no produto da arrecadação do ICMS em SC, conforme critério do VA.

Quadro 2 - Índice dos 12 municípios com a maior participação no produto da arrecadação do ICMS para o exercício de 2018

\begin{tabular}{|l|c|c|c|c|}
\hline \multicolumn{1}{|c|}{ Municípios } & $\begin{array}{c}\text { Valor Adicionado } \\
\text { Ano 2016 }\end{array}$ & $\begin{array}{c}\text { Participação dos } \\
\text { municípios (\%) - } \\
\mathbf{2 0 1 8}\end{array}$ & $\begin{array}{c}\left.\text { Território } \mathbf{( K m}^{2}\right) \\
\text { Censo 2016 }\end{array}$ & $\begin{array}{c}\text { População } \\
\text { Censo 2010 }\end{array}$ \\
\hline Joinville & $17.872 .590 .550,20$ & 8,6036147 & 518,497 & 309,011 \\
\hline Itajaí & $15.264 .456 .096,58$ & 7,2333176 & 288,286 & 183,373 \\
\hline Blumenau & $10.425 .972 .242,48$ & 4,8145518 & $1.126,106$ & 577,077 \\
\hline Florianópolis & $6.022 .704 .482,95$ & 2,8849813 & 675,409 & 421,240 \\
\hline Jaraguá do Sul & $5.563 .823 .036,05$ & 2,7989040 & 529,447 & 143,123 \\
\hline Chapecó & $5.003 .794 .820,49$ & 2,4303405 & 626,060 & 183,530 \\
\hline
\end{tabular}

\footnotetext{
${ }^{9}$ Mas quando um município cede parte de seu território à proteção e/ou conservação, essa parcela deixa de produzir bens e riquezas, que retornam a ele por meio dos tributos, nesse caso, o ICMS. Reiterando, os critérios de rateio do estado de Santa Catarina ocorrem, nos termos da Lei Estadual n.. 8.203 de 1990. Dos 100\% da arrecadação, 75\% ficam no estado e os $25 \%$ são assim divididos: $85 \%$ distribuídos de forma proporcional ao valor adicionado realizado em cada município e $15 \%$ distribuídos de forma igualitária entre os municípios.
} 


\begin{tabular}{|l|c|c|c|c|}
\hline \multicolumn{1}{|c|}{ Municípios } & $\begin{array}{c}\text { Valor Adicionado } \\
\text { Ano 2016 }\end{array}$ & $\begin{array}{c}\text { Participação dos } \\
\text { municípios (\%) - } \\
\mathbf{2 0 1 8}\end{array}$ & $\begin{array}{c}\text { Território }\left(\mathbf{K m}^{2}\right) \\
\text { Censo 2016 }\end{array}$ & $\begin{array}{c}\text { População } \\
\text { Censo 2010 }\end{array}$ \\
\hline São José & $4.865 .530 .541,99$ & 2,3702849 & 150,453 & 209,804 \\
\hline Lages & $4.062 .904 .583,22$ & 1,9329042 & 2.631 .504 & 156,727 \\
\hline Criciúma & $3.634 .660 .189,12$ & 1,8468707 & 235,701 & 192,308 \\
\hline Brusque & $3.449 .504 .168,76$ & 1,6775529 & 283,223 & 105,503 \\
\hline São Francisco do Sul & $3.057 .594 .486,35$ & 1,4156277 & 498,646 & 42,520 \\
\hline Palhoça & $2.399 .777 .308,23$ & 1,1695281 & 395,133 & 137,334 \\
\hline
\end{tabular}

Fonte: Elaborado pelos autores deste capítulo a partir de Santa Catarina (2018) e IBGE $(2016,2017)$

No Quadro 3, consta os 12 municípios com as menores participações no produto de arrecadação do ICMS, conforme a Secretaria da Fazenda do estado de Santa Catarina (SEFAZ).

Quadro 3 - Índice dos 12 municípios com a menor participação no produto da arrecadação do ICMS para o exercício de 2018

\begin{tabular}{|l|c|c|c|c|}
\hline \multicolumn{1}{|c|}{ Municípios } & $\begin{array}{c}\text { Valor Adicionado } \\
\text { Ano 2016 }\end{array}$ & $\begin{array}{c}\text { Índice de participação } \\
\text { dos municípios (\%) - } \\
\mathbf{2 0 1 8}\end{array}$ & $\begin{array}{c}\text { Território (Km2) } \\
\text { Censo 2016 }\end{array}$ & $\begin{array}{c}\text { População } \\
\text { Censo 2010 }\end{array}$ \\
\hline Pescaria Brava & $21.254 .460,78$ & 0,0647281 & 105,169 & 9980 \\
\hline Rio Rufino & $23.207 .427,92$ & 0,0656092 & 282,504 & 2.436 \\
\hline Presidente Nereu & $22.760 .305,67$ & 0,0661196 & 225,661 & 2.284 \\
\hline Irati & $30.954 .483,64$ & 0,0666459 & 77,276 & 2.096 \\
\hline Celso Ramos & $31.104 .194,51$ & 0,0674686 & 208,323 & 2.771 \\
\hline Matos Costa & $33.982 .389,35$ & 0,0680849 & 433,073 & 2.839 \\
\hline Barra Bonita & $32.716 .420,45$ & 0,0682671 & 93,108 & 1,878 \\
\hline Cerro Negro & $38.101 .600,10$ & 0,0683027 & 417,335 & 3.581 \\
\hline Balneário Arroio do & $33.238 .573,87$ & 0,0686755 & 95,259 & 9.586 \\
\hline Silva & $34.438 .996,46$ & 0,0695016 & 73,836 & 1.465 \\
\hline Santiago do Sul & $36.918 .018,78$ & 0,0704170 & 542,120 & 3.214 \\
\hline Anitápolis & $37.504 .191,74$ & 0,0705123 & 145,762 & 8.234 \\
\hline Balneário Gaivota & & & & \\
\hline
\end{tabular}

Fonte: Elaborado pelos autores deste capítulo a partir de relatórios de Santa Catarina (2018) e IBGE $(2016,2017)$ 
Analisar a distribuição do VA, com base na extensão territorial de um município bem como em relação à população que nele reside, conforme Gerber (2004, p. 86), [...] é muito importante para a avaliação dos impactos das mudanças nos critérios de distribuição do imposto [...] se analisar isoladamente pode não conter respostas para inúmeras perguntas, mas a sua correlação com outras variáveis pode ser elucidativa". Portanto, existem municípios que possuem grande extensão territorial ou um número populacional considerável, mas contam com pouca produção, e consequentemente terão um valor menor de distribuição do produto do ICMS.

Nesse aspecto, o ICMS-E caminha juntamente com os preceitos do ecodesenvolvimento, cujos objetivos "[...] são sempre sociais, há uma condicionalidade ambiental que é preciso respeitar, e finalmente, para que as coisas avancem, é preciso que as soluções pensadas sejam economicamente viáveis." (SACHS 2009a, p. 232). Para tanto, por si só, o cuidado ambiental não ocorre e aí então o ICMS-E se apresenta como "[...] o mais importante mecanismo compensatório ou de incentivo à preservação existente no país." (GERBER, 2004, p. 89).

Por fim, cabe ressalvar que a preservação e/ou conservação ambiental não deve ser encarada como redução no crescimento econômico e a exploração do meio ambiente não é garantia de desenvolvimento da economia, conforme a teoria ecodesenvolvimentista. E aqui, encontrarse-ia então o fundamento do ICMS-E, que objetiva o equilíbrio entre ambos, para assim desenvolver-se de forma sustentável, atendendo às necessidades das presentes e futuras gerações, nas dimensões econômica, espacial/territorial, cultural, ecológica, ambiental, social e política. 


\section{DISCUSSÃO ACERCA DO ECODESENVOLVIMENTO E POLÍTICAS PÚBLICAS REDISTRIBUTIVAS PERANTE AS PERSPECTIVAS DE IMPLEMENTAÇÃO DO ICMS-E} EM SC

Analisar a discussão para a implementação de uma política tributário-ambiental requer cautela. Seja porque se trata de um tema sensível num país que já possui uma das cargas tributárias mais elevadas do mundo, seja porque ele envolve a questão ambiental, expressa como um direito fundamental previsto no artigo 225 da Constituição Federal (THOMÉ DA SILVA, 2015).

Entretanto, não há percepção de um cenário de discussão de políticas públicas tributário-ambientais tanto nos espaços políticos quanto da sociedade em geral. Esse desinteresse criou uma vacância de novas políticas ambientais no Brasil, trazendo como exemplo a política pública objeto deste estudo, que teve sua última implementação no estado de Goiás no ano de 2011, passando-se assim, oitos anos sem novas implementações (ICMS ECOLÓGICO, 2017).

Como essa análise está para uma perspectiva futura, com sua implementação, o projeto de SC iria ao encontro da dupla proposição do ecodesenvolvimento, "solidariedade com as gerações presentes e futuras" e também a exigência de critérios de "sustentabilidade social e ambiental e de viabilidade econômica" (SACHS, 2008, p. 36). Isso porque, desde a década de 1970 há debates sobre os problemas ambientais e ações precisaram ser colocadas em prática. Em razão dos problemas com o meio ambiente em nível global, houve uma "[...] ampla reconceitualização do desenvolvimento, em termos de ecodesenvolvimento." (SACHS, 2008, p. 36) com destaque para a primeira década deste século XXI.

Por envolver variadas esferas governamentais e englobar diversos pontos de divergência, é possível, nesse caso, avaliar o valor das políticas públicas, "[...] como meio de atender às demandas prementes e promover possíveis avanços e mudanças sociais a partir das decisões tomadas, das escolhas feitas e dos caminhos traçados, em relação às 
estratégias de intervenção realizadas." (GIANEZINI, K. et al., 2017, p. 1.066). Nesse cenário - que Sabatier e Jenkin-Smith (1993) se referem como um sistema ou subsistema de política pública, por haver uma pluralidade de atores/agentes envolvidos no processo de implantação - a abordagem de "coalizão de defesa" se faz presente, afinal são crenças, valores e ideias que podem se concertar entre os envolvidos.

Por conseguinte, cabe mencionar que nessa trajetória de construção e tentativa de implementação, houve reuniões, fóruns de discussões e simulações, criados na tentativa de mostrar à sociedade o grau de importância das áreas de proteção ambiental que constam em seus territórios em relação ao desenvolvimento local. Todo esse trâmite da época foi apurado na pesquisa documental e consta em documentos disponibilizados na Assembleia Legislativa de SC.

Assim, em conclusão a esta última subseção, são apresentadas a seguir duas destas "propostas" identificadas nas falas e complementadas com a documentação pesquisada.

A primeira é o Projeto de Lei Complementar n. 010/2003, na qual em sua fase de elaboração ocorreram diversas alterações para escolher os melhores critérios de distribuição, restando assim a seleção daqueles considerados essenciais ao nosso estado: Receita Própria; População; Área do Município; Cota Igual; Educação Ambiental; Saneamento Ambiental; Mananciais de Abastecimento Público e Unidades de Conservação/Terras Indígenas. Nessa proposta, os critérios recaiam sobre os $25 \%$ que já é distribuído aos municípios e que nesse caso, alterava a redistribuição existente, criando assim, critérios ecológicos.

Já a segunda proposta, o Projeto de Lei Complementar $n$. 035.7/2011, veio com outra "roupagem", criando outros critérios e forma de distribuição. Nesse, o valor de distribuição do ICMS seria da parte que fica com o estado, os $75 \%$ e os critérios além de todos os elencados no projeto inicial, apresentava a proposta de educação ambiental, com iniciativas nos colégios espalhados pelo estado.

Ocorre que, esse projeto de lei visava a alterar as receitas orçamentarias do estado e nesse caso, por tal alteração, a propositura não pode ser via poder legislativo, mas sim pelo poder executivo com 
base no artigo 165 da Constituição Federal. Portanto, sendo o ICMS a maior fonte de renda na esfera estadual (SANTA CATARINA, 2018) e, consequentemente, responsável por parte do orçamento dos estados, ao passar pela CCJ o projeto foi arquivado por vício na origem.

Um dos fatos mais relevantes constatados na pesquisa de campo e nas entrevistas com os agentes, foram as reiteradas tentativas distintas de implementação. Contudo, constatou-se que a falta de interesse por parte dos municípios e da FECAM que impossibilitou alcançar o objetivo, ficando aqui caracterizada a inexistência de uma coalizão de causa como preconizado pelo modelo ACF (LUKIC, 2012). Sendo assim, enquanto tal política pública tributário-ambiental não é implementada, a realidade que se apresenta é a de municípios mais industrializados, que continuam mantendo suas atividades e consequentemente com maior valor redistribuído a título de ICMS, enquanto que os municípios que possuem área de preservação e/ou conservação continuam limitados de produzir, arcando com o ônus de tal responsabilidade.

Mesmo que não seja sua responsabilidade constitucional assinalam-se ações isoladas em alguns pequenos munícipios, que lutam para contemplar - em maior ou menor grau, de forma direta ou indireta, consciente ou inconscientemente - em seus planos de desenvolvimento, as dimensões de sustentabilidade (econômica, espacial/territorial, cultural, ecológica, ambiental, social e política) preconizadas pelo ecodesenvolvimento.

Tal constatação encontra ao final desta seção, uma reflexão resultante de interpretação da Constituição Federal de 1988, no que concerne ao disposto no artigo 170, inciso $\mathrm{VI}$, aliado com a previsão contida no artigo 155 , parágrafo $2 \stackrel{2}{ }$, inciso III.

Art.170 A ordem econômica, fundada na valorização do trabalho humano e na livre iniciativa, tem por fim assegurar a todos existência digna, conforme os ditames da justiça social, observados os seguintes princípios: [...] VI - defesa do meio ambiente, inclusive mediante tratamento diferenciado conforme o impacto ambiental dos produtos e serviços e de seus processos de elaboração e prestação. (BRASIL, 1988, grifo nosso). 
Considera-se assim, que o ICMS-E também pode ser utilizado como instrumento de ordenação político-econômico, estimulando a prática de operações ou prestações ambientalmente desejadas, tendo como fim a busca por um meio ambiente ecologicamente equilibrado previsto no artigo 225.

\section{CONSIDERAÇÕES FINAIS}

As leituras e o levantamento documental prévio ao estudo demonstravam que dos 26 estados do Brasil (e o Distrito Federal), 16 já implementaram o ICMS-E como instrumento de política pública tributário-ambiental, para compensar os territórios que possuem áreas de preservação e/ou conservação, com restituição financeira por tal atitude. Essa prévia representa também o ponto de partida da pesquisa e agora encontra as considerações.

O primeiro específico era promover um levantamento, com mapeamento dos estados que já implementaram o ICMS-E. O quadrosíntese e figura constando o mapeamento foram apresentados na seção de resultados, incluindo o ano de implementação, as alterações legislativas, percentual de repasse e os critérios ecológicos de distribuição foi o recurso encontrado para contemplar essa etapa e serviu para confrontar a condição de SC perante os demais estados.

O segundo era compilar os requisitos e as informações relacionadas às ações de implantação do ICMS-E em Santa Catarina junto aos órgãos competentes e associações. O terceiro necessitava averiguar os avanços e retrocessos no processo de implantação dessa política governamental. Para tanto, recorreu-se ao levantamento documental, aliado à percepção dos entrevistados, o que revelou uma participação limitada e por vezes individualizada (ou mesmo isolada) dos agentes da proposta.

O quarto e último objetivo proposto foi analisar os argumentos para implementação ou não do ICMS-E em Santa Catarina. Os argumentos evidenciados dentre os agentes envolvidos foi que os municípios maiores não possuem interesse em tal implementação, pelo fato de diminuir 
sua parcela de ICMS previsto constitucionalmente. Carecendo então de novas medidas para essa problemática. Constatou-se que o processo de implantação contou com o apoio de determinadas organizações como a FATMA e a FECAM - e representantes da sociedade. Destaca-se que, embora fosse importante em decorrência da natureza complexa da temática, não houve um significativo engajamento da sociedade em geral. Depois de sua elaboração, o processo tramitou na Assembleia Legislativa até ser arquivado por falta de aprovação, em 22 de fevereiro de 2011. E como não se realizou uma análise comparada e nem se estudou especificamente o caso de cada estado-membro, se observou um contexto no qual há a percepção de que sua aprovação ainda é utópica, pois, atualmente, não existe nenhum projeto tramitando sobre ICMS-E no estado.

Os agentes envolvidos no projeto de proposição de implantação do Projeto de Lei Complementar que buscava implementar o ICMS Ecológico em Santa Catarina (n. 010/2003), foram essenciais para a construção e conclusão deste estudo. Isso porque, foi por meio das informações declaradas nas entrevistas que se conseguiu compreender o objeto pesquisado. Neste ponto cabe mencionar que a entrevista semiestruturada foi fundamental e se revelou a técnica mais apropriada para a pesquisa de campo, permitindo a compreensão doo ciclo desse projeto - desde a motivação que levou a propositura até o seu arquivamento.

Reitera-se aqui a ideia de que o ICMS é um instrumento muito importante para a preservação e/ou conservação ambiental, podendo ser vista como uma política pública tributária-ambiental aliada não apenas nas questões ambientais, mas também nas questões sociais e econômicas. Por conseguinte, acredita-se que uma possível contribuição deste estudo para o estado de SC, está no fato de apresentar abordagem interdisciplinar e discussão acerca das políticas públicas e do ecodesenvolvimento. E, finalmente, em âmbito regional, o trabalho pode contribuir para uma compreensão acerca do seu papel e participação na proteção do meio ambiente para contribuir no desenvolvimento socioeconômico local.

Caracterizando-se como um estudo ex ante, entende-se que a pesquisa apresentou algumas limitações, em especial o tempo que 
ocorreram as discussões do projeto do ICMS-E. Outro fator limitante foi o fato de existir apenas um projeto de lei apto a ser estudado, haja vista que o segundo projeto não superou a fase de aprovação na CCJ. A existência de outros projetos poderia conferir uma percepção mais consistente e indicaria maior propensão à implementação do ICMS-E em SC. Ademais, pode-se mencionar alguns pontos nas entrevistas: por se tratar de um projeto relativamente "antigo", houve participantes que não se recordavam de situações ocorridas naquele contexto e que poderiam contribuir na acurácia dos resultados dessa pesquisa.

\section{REFERÊNCIAS}

ALVES, B. M.; ALBUQUERQUE, L. Implicações econômicas do princípio do poluidor pagador e a criminalização da conduta corporativa lesiva ao meio ambiente. In: CONPEDI/UNICURITIBA II. Direto ambiental e socioambientalismo. Florianópolis: CONPEDI, 2016. p. 75-95.

BARBIERI, J. C. Gestão ambiental empresarial: conceitos, modelos e instrumentos. 3. ed. atual e ampliada. São Paulo: Saraiva, 2011.

BRASIL. Constituição 1988. Constituição da República Federativa do Brasil. Brasília, DF, 1988. Disponível em: http://www.planalto.gov.br/ccivil_03/constituicao/constituicao.htm.

Acesso em: 19 jun. 2019.

BRASIL. Lei Complementar n. 92, de 23 de dezembro de 1997. Altera a legislação do imposto dos Estados e do Distrito Federal sobre operações relativas à circulação de mercadorias e sobre prestações de serviços de transporte interestadual e intermunicipal e de comunicação. Brasília, DF, 1997. Disponível em: http://www.planalto.gov.br/ccivil_03/leis/lcp/Lcp92.htm. Acesso em: 9 maio 2018.

BRUNDTLAND, G. H. Our common future: the world commission on environment and development. Oxford: Oxford University Press, 1987.

CHIANCA, T.; MARINO, E.; SCHIESARI, L. Desenvolvendo a cultura de avaliação em organizações da sociedade civil. São Paulo: Global, 2001. (Coleção Gestão e Sustentabilidade). 
COHEN, E.; FRANCO, R. Avaliação de projetos sociais. 7. ed. Petrópolis: Vozes, 2007.

CONSELHO NACIONAL DE POLÍTICA FAZENDÁRIA (CONFAZ). Ministério da Fazenda. Boletim de Arrecadação, 2018. Disponível em:

https://www.confaz.fazenda.gov.br/legislacao/boletim-do-icms/SC. Acesso em: 20 fev. 2018.

CRESWELL, J. W. Projeto de pesquisa: métodos qualitativo, quantitativo e misto. Tradução de Magda Lopes. 3. ed. Porto Alegre: Artmed, 2010.

FERREIRA, L. da C. A questão ambiental: sustentabilidade e políticas públicas no Brasil. São Paulo: Boitempo Editorial, 1998.

FREY, K. Políticas Públicas: um debate conceitual e reflexões referentes à prática da análise de políticas públicas no Brasil. vol. 21. Brasília, DF: IPEA, 2000. (Planejamento e Políticas Públicas).

GERBER, J. C. ICMS-Ecológico: um instrumento econômico de apoio à sustentabilidade. 2004. 311 f. Tese (Doutorado em Engenharia de Produção) - Programa de Pós-Graduação em Engenharia de Produção. Universidade Federal de Santa Catarina, Florianópolis, 2004.

GIANEZINI, K. et al. Políticas Públicas: definições, processos e constructos no século XXI. Revista de Políticas Públicas (UFMA), São Luís, MA, v. 21, n. 2, p. 1.065-1.084, 2017.

GIANEZINI, M. et al. A evolução de eventos sobre meio ambiente e seus reflexos na responsabilidade socioambiental das empresas: reflexões para a conscientização ambiental. Educação Ambiental em Ação, Porto Alegre, n. 39, Ano X, p. 1.185, mar./maio 2012.

GIANEZINI, M. et al. Tipos de avaliação de projetos sociais. In: GIANEZINI, M. (org.). Introdução à avaliação e ao monitoramento de projetos sociais. Inter Saberes, Curitiba, v. 1, p. 39-50, 2017.

GONÇALVES, J. P.; GIANEZINI, M.; ESTEVAM, D. Políticas sociais habitacionais rurais no extremo Sul de Santa Catarina. Revista de Políticas Públicas (UFMA), São Luís, MA, v. 22, n. 1, p. 365-396, 2018. 
ICMS ECOLÓGICO. Site Institucional. Portal virtual. 2017. Disponível em: http://www.icmsecologico.org.br/site/index.php?option=com_content\&view=article\&id=53\&ltemid=60\#up. Acesso em: 4 maio 2018.

INSTITUTO BRASILEIRO DE GEOGRAFIA E ESTATÍSTICA (IBGE). Informações das culturas permanentes e temporárias do Brasil. 2016. Disponível em: http://seriesestatisticas.ibge.gov.br/lista_tema.aspx?op=0\&no=1. Acesso em: 12 jan. 2018.

INSTITUTO BRASILEIRO DE GEOGRAFIA E ESTATÍSTICA (IBGE). Número de municípios em Santa Catarina. 2017. Disponível em: http://www.ibge.gov. br/estadosat/perfil.php?sigla=sc. Acesso em: 7 maio 2018.

KHANDKER, S. R.; KOOLWAL, G. B.; SAMAD, H. A. Handbook on impact evaluation. Quantitative methods and practices. Washington, DC: The World Bank, 2010.

LASSWELL, H. D. Politics: who gets what, when, how. New York; London: Whittlesey house, McGraw-Hill book company, 1936.

LOWI, T. Four Systems of Policy, Politics, and Choice. Public Administration Review, [s.I.], v. 32, p. 298-310, jul./ago. 1972.

LUKIC, M. S. R. A tributação no Brasil analisada a partir da abordagem cognitiva de Políticas Públicas. Revista Ética e Filosofia Política, Juiz de Fora, v. 1, n. 17, p. 8-36, maio 2012.

RAEDER, S. T. O Ciclo de Políticas: uma abordagem integradora dos modelos de análises de Políticas Públicas. Perspectivas em Políticas Públicas, Belo Horizonte, v. VII, n. 13, p. 121-146, jan./jun. 2014.

SABATIER, P. A.; JENKINS-SMITH, H. (dir.). Policy change and learning: an advocacy coalition approach. Boulder, CO: Westview Press, 1993.

SACHS, I. A terceira margem: em busca do ecodesenvolvimento. Tradução de Rosa Freire d'Aguiar. São Paulo: Companhia das Letras, 2009a.

SACHS, I. Caminhos para o desenvolvimento sustentável: ideias sustentáveis. STROH, Paula Yone (org.). Rio de Janeiro: Garamond, 2009b. 
SACHS, I. De volta à mão visível: os desafios da Segunda Cúpula da Terra no Rio de Janeiro. Estudos Avançados, São Paulo, v. 26, n. 74, p. 7-20, 2012.

SACHS, I. Desenvolvimento: includente, sustentável, sustentado. Rio de Janeiro: Garamond, 2008.

SACHS, I. Em busca de novas estratégias de desenvolvimento. Estududos Avançados, [online], São Paulo, v. 9, n. 25, p. 29-63, 1995.

SACHS, I. Estratégias de transição para o século XXI: desenvolvimento e meio ambiente. São Paulo: Studio Nobel/Fundap, 1993.

SACHS, I. O problema da democracia econômica e social. Estudos Avançados, São Paulo, v. 8, n. 21, 1-15, 1994. Disponível em: http://www.scielo.br/pdf/ ea/v8n21/02.pdf. Acesso em: 5 maio 2018.

SANTA CATARINA. Secretaria de Estado da Fazenda. Valor adicionado aos municípios. 2018. Disponível em: http://www.sef.sc.gov.br/servicos/servico/92/ Valor_adicionado_por_munic\%C3\%ADpio_e_atividade. Acesso em: 14 jun. 2018.

SANTA CATARINA. Lei $\mathbf{n} . \mathbf{8 . 2 0 3}$, de 26 de dezembro de 1990. Altera o critério de distribuição do ICMS aos municípios. ALESC, 1990. Disponível em: http:// leis.alesc.sc.gov.br/html/1990/8203_1990_Lei.html. Acesso em: 14 jun. 2018.

SARAIVA, E. Introdução à Teoria Política Pública. In: SARAIVA. E. FERNANDES, E. (org.). Políticas Públicas. vol. 1. Brasília, DF: ENAP, 2006.

SCHMIDT, J. P. Para entender as políticas públicas: aspectos conceituais e metodológicos. In: REIS, J. R. dos; LEAL, R. G. (org.). Direitos sociais e políticas públicas: desafios contemporâneos. Tomo 8. Santa Cruz do Sul: Edunisc, 2008. p. 2.307-2.333.

SECCHI, L. Políticas públicas: conceitos, esquemas de análise, casos práticos. 2. ed. São Paulo: Cengage Lerning, 2015.

SELLTIZ, C. et al. Métodos de pesquisa nas relações sociais. São Paulo: Herder/Edusp, 1967. 
SOUZA, C. Políticas Públicas: uma revisão da literatura. Sociologias, Porto Alegre, Ano 8, n. 16, p. 20-45, jul./dez. 2006.

THOMÉ DA SILVA, R. F. Manual de direito ambiental. Salvador: Jus Podivm, 2015. 